\title{
Analysis of the Expansion of Punitive Damages in the Tort Liability of Intellectual Property Rights
}

\author{
Wenfeng $\mathrm{Xu}$ \\ Guangzhou Maritime University, Guangdong Province, Guangzhou City 510725, China \\ xuwenfeng@126.com
}

Keywords: intellectual property right, tort liability, punitive damages, expansion

\begin{abstract}
With the continuous development of China's economy and science and technology, the role of knowledge in people's daily life is becoming more and more obvious. Intellectual property has gradually been recognized and accepted the public, in order to protect the basic rights and intellectual development enterprises enthusiasm, the state promulgated and revised "trademark law", "patent law", "copyright law" three laws. However, compared with foreign intellectual property protection, protection of intellectual property rights in China is mainly to the compensatory compensation principle, to curb violations of intellectual property rights results are poor, so learn from foreign experience, and constantly improve the National Intellectual Property Protection Act has become an important problem in jurisprudence thinking. In this paper, the author analyzes the punitive damages in the infringement of intellectual property rights in our country.
\end{abstract}

\section{Introduction}

The professional knowledge of intellectual property object can bring huge economic benefits to the obligee, and has great economic value. However, it is still driven by interests. Unscrupulous competitors or investors in order to achieve their own interests, infringe the intellectual property right, the obligee suffered huge losses of [1], so take effective measures to minimize the loss of human rights has become the key of intellectual property legislation. At present, the law of the state is mainly to redress the imbalance of interests caused by the intellectual property rights, so as to protect the enthusiasm of legal person, natural person, or other organizations in the investment innovation.

\section{Damage compensation system and defects in the three legislation}

At present, China's intellectual property laws and regulations, in compensation for the rights of people, the actual amount of compensation for damage to the rights of people should be lost to the provisions of the national "patent law" sixty-fifth stipulates "the amount of compensation for the infringement of patent right in accordance with the actual loss of the obligee for copyright infringement has been determined by" however, the "trademark law" in Article 56 on the basis of the compensation provisions, "the amount of compensation for infringement of trademark infringement, the infringer during the period for infringing the benefits or infringement in the infringement during the damage caused by the infringement, including the reasonable expenses paid by the to stop the infringement tort." In the 48 article of the copyright law, the author puts forward that the copyright infringement or copyright related rights shall be compensated by the infringer in accordance with the actual loss of the obligee." In recent years, with the increasing number of infringement cases, the defects in the implementation of laws and regulations are gradually revealed, in order to supplement the defects, the Supreme People's Court issued the order "on the infringement of trademark infringement and how to calculate the amount of compensation for losses during the problem of" reply, on the trial of patent disputes answer "two judicial interpretation, further make clear provisions on tort compensation. Through the summary of the above analysis, we can find that, at present, China's legal system has been paid attention to the problems of punitive damages, and the protection of the legitimate rights and interests of the right holder. 


\section{Realistic basis and theoretical basis of punitive damages}

The realistic basis of punitive damages. With the rapid growth of China's economy and science and technology, the enthusiasm of all walks of life has been greatly improved. However, with the increase of IPR infringement cases,survey data show that from the beginning of 2008 to the first half of 2016, the national courts handled 226753 IPR cases, of which 20596 criminal cases of intellectual property rights, 9948 IPR administrative cases, 196209 civil cases of intellectual property right. Since the beginning of 2008 to 2011, a trial of intellectual property cases about a year to maintain growth of 33\%, significantly higher than that of the general civil cases compared to an increase of 26.3 percentage points, has brought more and more pressure of [2] for the trial of intellectual property rights. The technology involves complicated facts of the case, decided the enterprise survival results of the referee cases, require clear and specific legal limits of the dark cases increased significantly, the existing laws and regulations need to be perfected and supplemented, and the parties to resolve disputes is also significantly increased. At present our country in the current intellectual property protection is not optimistic, the high cost of rights and infringement issues lead to low cost, human rights violations after the huge loss of property, but the compensation is few, the minimum is only 30 yuan, even with the highest billion yuan, but the average amount of compensation to less than one hundred thousand yuan. At the same time the infringer infringement by the great benefits, and the legal judgment of compensation is only one of the interests of some even thousands of, cannot achieve much deterrent effect, unable to contain the next occurrence of tort, therefore take place become more effective measures to curb piracy problems need legislation thinking.

Theoretical basis of punitive damages system. Punitive damages refers to the infringement, infringement of the rights of human rights have been violated and the implementation, has a major fault in the line, in addition to nominal compensation and compensation, in order to pay the party's bad behavior of compensation and punishment, in order to curb its possible implementation of the similar behavior of compensation for punitive damages, therefore is also called the "exemplary" compensation principle, its main purpose is to punish and restrain its pursuit after the bad. Punitive damages in Anglo American law system as an important system, such as the case of pollution, the protection of consumer rights cases and intellectual property cases. In recent years, China's legislative bodies continue to absorb the important system of intellectual property protection law in foreign countries, and successively promulgated the punitive compensation system, such as the 1993 "consumer protection law" in the "double" of punitive damages system, after ten years of development, in 2009 promulgated the "tort liability law" and "food safety law" on the protection of intellectual property rights, punitive damages in the position of the clear rules. Punitive damages are mainly for the purpose of punishing and preventing the infringement. Foreign scholars believe that, if the defendant in the conduct of infringement, malicious, very poor means of infringement and brought huge losses to the plaintiff, the defendant may be sentenced to claim compensation for damages [3]. Because if the defendant is only the general liability for compensation and double liability, can not guarantee the seriousness and legitimacy of the law, while the effect of punishment and deterrence is not obvious. With the increasing openness of the international community, the practice of foreign legislation also provides a reference for China's intellectual property tort liability for punitive damages. The United States "patent law" article two hundred and eighty-four of the law: the plaintiff in evidence, the court asked the accused infringed degree given adequate compensation in accordance with the patent, the number of compensation to meet at least the infringer need in the development process of the reasonable patent licensing fees, litigation costs, and the interest rate. If the jury is unable to estimate the amount of damage to the victim, the court evaluates the amount. In any case, the court may increase the amount of damages assessed by the court or the amount of compensation awarded by the jury 3 times. South Korea "patent law" provisions of article 128, if the patent right of the patentee's accused of intentional or negligent of infringement and caused economic losses of the patentee, the patentee is able to apply to the court for the defendant compensation beyond the actual damages punitive damages [4]. The "trademark law", "copyright law", "patent law" and so on are all made clear to the punitive damages liability. These bills provide 
the theoretical basis for the amendment of the punitive damages liability in China's copyright law, trademark law, patent law, and the three bills.

However, some scholars in China put forward the provisions of punitive damages, intellectual property right is a private right, so when subjected to violations of intellectual property rights, should be in accordance with the private remedy, the infringer to bear the compensation to fill the principle and the principle of compensation is appropriate, so that the punitive compensation responsibility and the spirit of the civil law violation, violation the principle of [5] fairness. They believe that punitive damages lead to public power into the private sphere, resulting in the parties in the legal status of tilt. Although this idea has certain rationality, but there are obvious historical limitations. More importantly, this view completely ignored the civil rights and intellectual property rights, neglects the particularity of intellectual property rights. Intellectual property rights is immaterial, this point especially the property and civil rights have great differences, in particular has three basic characteristics: first, as long as the object of intellectual property right in front of the public, it actually is not easy to be the owner of intellectual property management and control, so that the general public can according to their own will the control; secondly, intellectual property can be more people to use and there will not be any conflict between them; thirdly, the object of intellectual property value cannot be estimated accurately. This leads to the once the object of intellectual property may need to bear once reveal to the public, by others whenever and wherever possible unauthorized use of the problem. After nearly 400 years of development history, the western developed countries through the establishment of intellectual property rights, intellectual property rights consciousness of ordinary people is relatively strong, good environment of intellectual property rights, infringement of intellectual property rights was also significantly lower, however, to effectively curb infringement events still preferred compensation efforts to improve, and punitive damages can to meet this requirement, a powerful deterrent.

\section{Foreign intellectual property rights punitive damages system}

The United States is the earliest in the provisions of the punitive damages system of intellectual property law in the country, while the United States compensation system is the most typical, "Uniform Trade Secret Law" in article third of the A and B have made provisions "if the infringement of patent malicious or intentional person occupation of human rights, the court may order the payment not more than 2 times the amount of compensation for punitive damages." "Lanham act" 35 provisions "in determining the amount of compensation, the court can carry any number of comprehensive judgment has identified damages, but must be controlled in less than 3 times,"

"Copyright law" Canada clearly stipulates that the disputes in copyright infringement, courts have the right of people to bear the right of compensation for damage and the infringer obtained due to the infringement of the profits are determined, and the determination of the amount of two, according to the circumstances of the crime to the infringer to assume a certain amount of punitive damages, punitive damages amount generally by the court according to the seriousness of the $\$ 5000$-50000 between judgment. In the tort liability law of the common law system, punitive damages amount as a basic system, which has been widely used in the judicial operation of most western countries, and has achieved good social evaluation [6].

\section{Suggestions on perfecting the system of punitive damages in China}

China's intellectual property law is mainly influenced by the continental law system, in the field of civil law is obviously affected by the German law, compensatory damages has been the legislative principle of civil compensation system, but after a long time of development, between the two legal systems of mutual transplantation has not uncommon [7]. In the past two years, with the development of the legislation system, the law of our country has accepted the punitive damages and established the clause. At present, there are two problems in the application of punitive damages system in the field of intellectual property law in China: how to judge the conditions of 
punitive damages and how to calculate the amount of punitive damages. First of all, the infringement of intellectual property damages the elements of civil liability mainly to obligee actual damage, the existence of the infringement, tort and the damage, the causal relationship between the infringement, subjective error. The author believes that the infringement of intellectual property rights should be treated as a general tort, the use of the principle of fault. First of all, the principle of fault liability and punishment to "consistent with this tradition, embodies the principle of reciprocity between the main responsibility; secondly, can effectively balance the rights of people, the infringer and the public interest; thirdly, the principle of fault liability is China's current judicial practice on the basis of intellectual property rights. "The amount of punitive damages for copyright infringement of the copyright law" is divided into three modes: according to the rights of people by the actual loss caused by the infringer to compensate according to the actual situation; the illegal infringement for compensation; if the two cannot accurately determine the amount of compensation, the court on the basis of malicious in the process of illegal infringement degree to determine the compensation shall not exceed 500 thousand yuan.

\section{Conclusion}

Punitive damages belong to the new topic in the protection of intellectual property rights in our country, with the national emphasis on the protection of intellectual property rights, "copyright law", "trademark law", "patent law" has been revised fourth times in the draft proposal to increase punitive damages. With the continuous improvement of the protection of intellectual property law, the awareness of the protection of intellectual property rights in all walks of life will be improved, effectively protect the national knowledge innovation, improve the enthusiasm of legal person, natural person and organization.

\section{References}

[1] H.D. Wu. The essence of institutional innovation and the goal of knowledge innovation in intellectual property law [J]. Research in law, 2014, (3): 95-108.( In Chinese)

[2] Z.Q. Yu. Review and future construction of criminal sanction system of IP crimes in China [J]. Chinese law, 2014, (3): 156-176. ( In Chinese)

[3] C.Y. Guo and Z.Y.Zhuang. Protection of intellectual property rights and independent innovation of "southern" countries [J]. economic research, 2012, (9): 32-45. ( In Chinese)

[4] S.M. Liu, P. Hou and Y.Y. Zhao. The protection of intellectual property rights and China industrial innovation capacity of large and medium-sized industrial enterprises from the provincial panel data empirical research on [J]. Quantitative and technical economics, 2015, (3): 40-57. ( In Chinese)

[5] G. Jiang. Copyright law and patent law in "punitive damages" non punitive [J]. law research, 2015, (6): 80-97. ( In Chinese)

[6] X.M. Cao. Punitive damages liability of intellectual property infringement: on the revision of three laws in the field of intellectual property rights of China [J]. intellectual property rights, 2013, (4): 3-9. ( In Chinese)

[7] N.X.Xu and J. Lian. The introduction of China's intellectual property law of punitive damages in [J]. Market modernization, 2012, 12 (under a): 633( In Chinese) 